\title{
Sustainability: An Introduction View from ICIEOM
}

\author{
Rui Manuel de Sá Pereira de Lima \\ Dinis Carvalho \\ University of Minho, Guimarães, Portugal
}

Guilherme Vaccaro

Universidade do Vale do Rio dos Sinos (UNISINOS), São Leopoldo, RS, Brazil

\section{Luiz Felipe Scavarda}

Pontifical Catholic University of Rio de Janeiro (PUC-Rio), Rio de Janeiro, RJ, Brazil

\begin{abstract}
This Special Issue of the Brazilian Journal of Operations and Production Management (BJOPM) features four papers selected from the XVIII International Conference on Industrial Engineering and Operations Management (ICIEOM), which conference theme was "Sustainability", and two invited papers based on keynote speeches regarding Sustainability and its association to Industrial Engineering fields (one from ICIEOM and the other from the ENEGEP conference). This editorial paper evaluates and summarizes these selected contributions as well as introduces the term sustainability.
\end{abstract}

Keywords: Industrial Engineering, Sustainability, Operations Management, Supply Chain Management, ICIEOM.

\section{Introduction}

The XVIII International Conference on Industrial Engineering and Operations Management (ICIEOM), held this year in Guimarães (Portugal), has encouraged communication among researchers and practitioners in the different fields of Industrial Engineering and Engineering Management. This time the conference has been shaped around sustainability fields. This Special Issue of the Brazilian Journal of Operations and Production Management (BJOPM) brings together four selected papers presented in the ICIEOM track entitled "Social Responsibility, Environment and Sustainability", in extended versions, plus two invited papers related to "sustainability" and Industrial Engineering that were the basis for plenary presentations at ICIEOM 2012 conference and at the ENEGEP 2012 (Encontro Nacional de Engenharia de Produção) conference, this last one held this year in Bento Gonçalves (Brazil).

Sustainability has increasingly become important to business research and practice over the past decades as a result of rapid depletion of natural resources and concerns over wealth disparity and corporate social responsibility (Dao et al., 2011). Sustainability means capability to go on for a long time. The use of this term goes back at least to the 1960s in economics and to the early 1970s in environmental management (Hansson, 2010). According to Appleton (2006), it is a problem statement that integrates 
the environment and the economy in a way that both sides can live with it and use as a new starting point for addressing what is basically the same problem that existed in 1970: how to restructure the relationship of the economy to the earth. For environmental or green interests, sustainability acknowledges the reality of the environmental crisis. For economic and status quo interests, sustainability acknowledges the legitimacy of economic growth to meet human needs. For both, it offers the possibility that each can co-exist with the other (Appleton, 2006).

Sustainability concerns to the principles of integrating economic, environmental and social imperatives, the so called triple bottom line. Achieving sustainable development requires a careful balance of these aspects, which are defined in Schönsleben et al. (2010) as follows:

- Environmental aspects refer to nature as a closed system with its limited resources and regenerative capacities (e.g., for greenhouse gases) as a base for any business activity;

- Economic aspects refer to events and facts relevant to manufacturing industries' competitiveness and their business practices, both strategic and operational;

- Societal aspects refer to society represented by governmental organizations, nongovernmental organizations, individuals, employees, and customers.

Interest in sustainability is growing, as evidenced by the number of papers published on different aspects of the subject. Figure 1 presents the number of papers retrieved, in the last two decades, based on a selected search using the ScienceDirect (Elsevier) database. In pseudo code, the following phrase was adapted to the search engine of the database within titles, abstracts and keywords: "sustainability" and "sustainable"; applied to the following subjects: "business, Management and Accounting", "computer science", decision science", "engineering", and "social science". The vertical axis presents the number of papers, while the horizontal axis presents the year of publication. The Chart includes the accumulative percentage of the total along the years, being $100 \%$ in 2012 . The search returned 1,995 published papers.

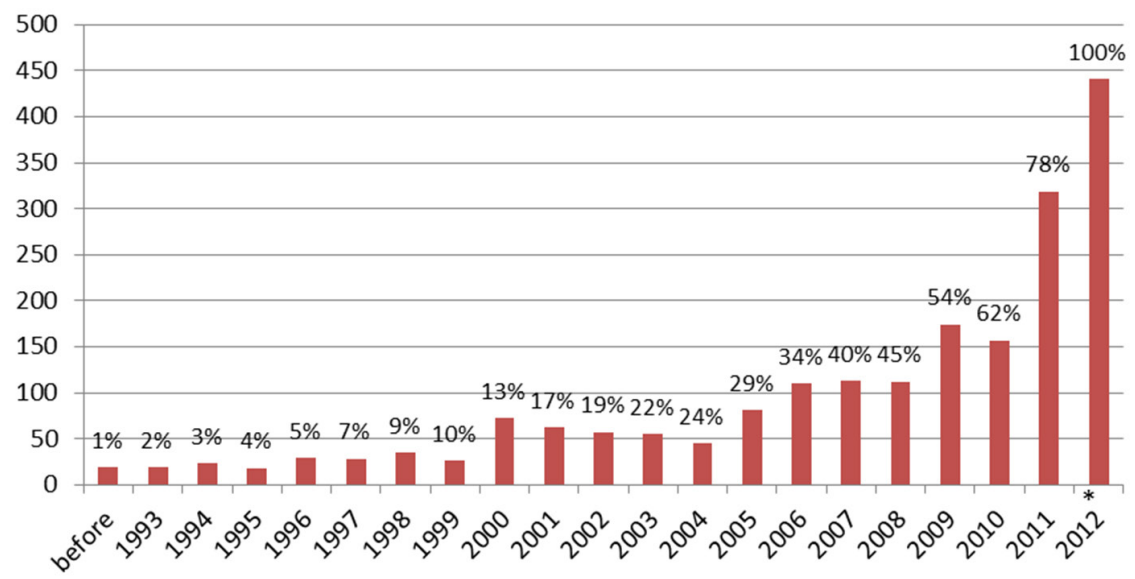

Figure 1. Growing number of published papers from Journals on sustainability until Oct. 2012. 
The growing number of publications on sustainability peaks in 2012, year that included papers based just on the period until October of 2012 (time this editorial was finished). More than $50 \%$ of the papers were published during the last 4 years (2009-2012), what reflects the importance given by the academy to "sustainability". These numbers exclude the gray literature ("scientific grey literature comprises newsletters, reports, working papers, theses, government documents, bulletins, fact sheets, conference proceedings and other publications distributed freely, available by subscription or for sale" - Weintraub, 2000, p. 54), as academics and professionals generally use academic journals to acquire knowledge and disseminate new results (Ngai et al., 2009).

The development of sustainability capabilities not only serves the environment and people, but also helps firms to generate value that could enhance profitability and gain sustained competitive advantage for themselves. This development requires a holistic approach by integrating different firm resources (Dao et al., 2011). Gold et al. (2010) go clearly beyond the firm level embracing inter-organizational resources. In their paper they argue that the paradigm shift from firm-level to supply-chain-level competition and the challenge of incorporating comprehensive sustainability goals into corporate behaviour due to worldwide growing environmental and ethical awareness induced the necessity for supply chains to act as quasi meta-organizations, coordinating information, material and financial flows internally from raw-material extraction to the final customer. Gold et al. (2010) also highlight that sustainability goals require even closer interaction between all firms involved, as ensuring simultaneously economic, environmental and social performance on a product's total life-cycle basis implies a much wider set of performance criteria to be met than it is the case in traditional supply chain management. This context embraces the sustainable supply chain management, that is defined in Seuring and Müller (2008, p. 1700) as

[...] the management of material, information and capital flows as well as cooperation among companies along the supply chain while taking goals from all three dimensions of sustainable development, i.e., economic, environmental and social, into account which are derived from customer and stakeholder requirements.

These authors also argue that in sustainable supply chains, environmental and social criteria need to be fulfilled by the members to remain within the supply chain, while it is expected that competitiveness would be maintained through meeting customer needs and related economic criteria.

Next, this editorial paper summarizes the selected articles that compose this special issue that are conducted by researchers from different countries and institutions: Brazil (Federal University of Paraná, Federal University of Santa Catarina, Federal University of Technology - Parana, Methodist University of Piracicaba, Pontifical Catholic University of Paraná, Santa Catarina State University and University Nine of July), France (Audencia Nantes School of Management), Spain (Universitat Politècnica de València), and United State of America (Crummer Graduate School of Business, Rollins College).

\section{Overview of the Special Issue Papers}

The papers of this special are classified into 3 groups. The first group embraces two papers that offer general considerations regarding sustainability concepts and 
trends applied in operations management, more specifically supply chain management. The first one is from Prof. Joe Miemczyk (Audencia Nantes School of Management, France) and embraces sustainable operations and supply chain management. The goal is to review some of the key challenges regarding this topic and to provide directions for future research. According to Prof. Miemczyk, sustainability raises many tradeoff situations and based on past experiences, recent research and current practices, he provides a framework for future research in sustainable operations and supply chain management. Prof. Henrique Corrêa (Rollings College, USA) presents and analyses in his paper supply chain management trends and offers an overview on how should managers prepare themselves for these tendencies within crossing borders perspective. The paper reviews the main supply chain management historical evolution phases, where the fifth one is related to "operations cross borders of the organization global objective - the triple bottom line (Economic prosperity, Environmental sustainability and, Social responsibility). The increase in the influence of organized society and governments to make organizations pursue this "triple bottom line" is considered a relevant trend for the management of global supply chains and the competences to deal with this increase are also discussed within the paper.

The second group of papers presents reviews of the literature. Mr. DíazMadroñero and Dr. Mula from the University of Valencia (Spain) analyse in their paper the current status of sustainable supply chain management and its application to the Book Publishing sector. They conclude with their review in the literature that there are several works dealing with individual sustainable practices, mainly the study of environmental impacts and the calculation of carbon footprint, but no references consider in an integrated way all partners in the supply chain Book Publishing industry (e.g. publishers, printers, distributors, retailers). Mrs Machado, Prof. Pinheiro de Lima, Prof. Gouvêa da Costa, Mrs Manfrin provide in their paper information on the integration of sustainability concepts within the Operations Management field as a discipline in Industrial Engineering. These authors analyse the aspects concerning sustainable development that have been worked out according to the operations and that have become relevant to researchers and offer an overview of trends for further research in sustainability within the Operation Management field.

The third group embraces empirical researches. Prof. Satolo, Mr. Calarge and Prof. Cauchick Miguel assess in their paper sustainability issues in the context of an integrated manufacturing system (IMS) using a multiple case study methodological approach. The goal is to identify relevant practices related to an IMS in four organizations belonging to the sugar cane and ethanol agricultural industrial sector in Brazil. An individual case description is made in addition to a cross-case comparison. These athors find evidence that there is a general concern for the environment within these organizations although this is demonstrated by a culture of reducing residuals and the control of waste of natural resources. Mrs. Trierweiller, Prof. Peixe, Prof. Tezza, Prof. Bornia and Prof. Lucila M. S. Campos verify in their paper the viability of using the Item Response Theory to measure Environmental Management evidence among industries in Brazil. The intention of such measurement is to evaluate the quality and propriety of each item individually, placing items and respondents on a single scale.

\section{Final Remarks}

The guest-editors of this special issue of the BJOPM believe that the papers of this special issue provide an interesting contribution to sustainability within some 
industrial engineering fields by offering a broad look at challenges and key innovations that occupy the minds of practitioners and academic researchers. Taken together, the papers constitute stimulating reading for different audiences in the different fields of industrial engineering.

\section{Acknowledgements}

The guest editors of this special issue would like to thank the support and incentive of Professor Helder Gomes, editor-in-chief of the Brazilian Journal of Operations and Production Management, Professor Vagner Cavanaghi, President of the Brazilian Association for Industrial Engineering (ABEPRO), and especially ICIEOMs publications committee. The development of this special issue would not have been possible without their involvement. The guest-editors also acknowledge the grateful help from the several special issue reviewers, who are top scholars from a diverse set of disciplines related to Industrial Engineering. Finally, the guest-editors are particulary indebted to the authors of the papers who have expended huge effort in following and respecting the stringent deadlines.

\section{References}

Appleton, A.F. (2006) Sustainability. Technology in Society, Vol. 28, No. 1-2, pp. 3-18. http://dx.doi.org/10.1016/j.techsoc.2005.10.001

Dao, V.; Langella, I. and Carbo J. (2011) From green to sustainability: Information Technology and an integrated sustainability framework. Journal of Strategic Information Systems, Vol. 20, No. 1, pp. 63-79. http://dx.doi.org/10.1016/j.jsis.2011.01.002

Gold, S.; Seuring, S. and Beske, P. (2010) Sustainable supply chain management and inter-organizational resources: a literature review. Corporate Social Responsibility and Environmental Management, Vol. 17, pp. 230-245.

Hansson, S.O. (2010) Technology and the notion of sustainability. Technology in Society, Vol. 32, No. 4, pp. 274-279. http://dx.doi.org/10.1016/j.techsoc.2010.10.003

Ngai, E.W.T.; Xiu, L. and Chau, D.C.K. (2009) Application of data mining techniques in customer relationship management: A literature review and classification. Expert Systems with Applications, Vol. 36, pp. 2592-2602. http://dx.doi.org/10.1016/j.eswa.2008.02.021

Schönsleben, P.; Vodicka, M.; Bunse, K. and Ernst, F.O. (2010) The changing concept of sustainability and economic opportunities for energy-intensive industries. CIRP Annals - Manufacturing Technology, Vol. 59, No. 1, pp. 477-480.

Seuring, S. and Müller, M. (2008) From a literature review to a conceptual framework for sustainable supply chain management. Journal of cleaner production, Vol. 16, pp. 1699-1710. http://dx.doi.org/10.1016/j.jclepro.2008.04.020

Weintraub, I. (2000) The impact of alternative presses on scientific communication. The International Journal on Grey Literature, Vol. 1, No. 2, pp. 54-59. http://dx.doi. org/10.1108/14666180010327195

\section{Biography}

Rui M. Lima is a lecturer at the University of Minho since 1995 and is currently Associate Professor in the Department of Production and Systems, Engineering School of the University of Minho. He is currently the course coordinator of Integrated Master in Industrial Engineering and Management. The main research interests are related to the planning and production control, project management, Lean production 
systems and education issues of Industrial Engineering and Management. He has been involved in the coordination of international conferences, including the "International Symposium on Project Approaches in Engineering Education (PAEE) since 2009," and the "International Conference in Industrial Engineering and Operations Management (ICIEOM 2012)." He has over 100 publications in international conferences, international journals and book chapters.

Contact:rml@dps.uminho.pt

José Dinis-Carvalho is a lecture at the University of Minho since 1995 and is currently Associate Professor in the Department of Production and Systems, Engineering School of the University of Minho. He is currently the course coordinator of the Master Course in Industrial Engineering. The main research interests are related to Lean production, project management and active learning approaches such as project and problem based learning. He has been involved in the coordination of international conferences, including the "International Symposium on Project Approaches in Engineering Education (PAEE) since 2009," and the "International Conference in Industrial Engineering and Operations Management (ICIEOM 2012)".

Contact:dinis@dps.uminho.pt

Guilherme Vaccaro is full tenure professor and researcher of the Masters in Production Engineering and Systems and of the Masters in Business Management at UNISINOS University of Rio dos Sinos Valley, and member of the board of the Brazilian Association of Production Engineering (ABEPRO). He holds a Ph.D. in Computer Science from Federal University of Rio Grande do Sul (2001), Master in Production Engineering from Federal University of Rio Grande do Sul (1997), Bachelor of Computational and Applied Mathematics from Federal University of Rio Grande do Sul (1993). He is reviewer of the International Journal of Production Research and other journals of national and international coverage in the field of Production Engineering. His research focuses are Quantitative Methods and Operations Management, acting on the following topics: innovation, modeling, simulation, optimization, DOE, reliability and multivariate methods. Currently he is at Sungkyunkwan University, South Corea, as Invited Researcher for post-doctoral studies at the Semiconductor Research Institute.

Contact: guilhermev@unisinos.br

Luiz Felipe Scavarda is Professor at the Industrial Engineering Department of PUC-Rio. Currently he is Head of the Department. His Graduate, Master, and Doctoral degrees in Industrial Engineering were obtained at PUC-Rio. His areas of expertise are in the field of supply chain management. During 2000/2002 he joined as visiting researcher the German Fraunhofer Institute for Manufacturing Engineering and Automation and in 2009 he was a post-doctoral fellow at the Vienna University of Technology. He has published in several international journals (e.g. International Journal of Operations \& Production Management and International Journal of Production Economics).

Contact: lf.scavarda@puc-rio.br

\section{Article Info:}

Received: August, 2012

Accepted: October, 2012 